\title{
Health status: does it predict choice in further education?
}

\author{
Leena Koivusilta, Arja Rimpelä, Matti Rimpelä
}

\begin{abstract}
Study objective - To study the significance of a young person's health to his or her choice of further education at age 16.

Design - A cross sectional population survey

Setting - The whole of Finland.

Participants - A representative sample of 2977 Finnish 16 year olds. The response rate was $83 \%$.

Measurements and main results - The three outcome variables reflected successive steps on the way to educational success: school attendance after the completion of compulsory schooling, the type of school, and school achievement for those at school. Continuing their education and choosing upper secondary school were most typical of young people from upper social classes. Female gender and living with both parents increased the probability of choosing to go on to upper secondary school. Over and above these background variables, some health factors had additional explanatory power. Continuing their education, attending upper secondary schools, and good achievement were typical of those who considered their health to be good. Chronically ill adolescents were more likely to continue their education than the healthy ones.

Conclusions - School imposes great demands on young people, thus revealing differences in personal health resources. Adaptation to the norms of a society in which education is highly valued is related to satisfying health status. In a welfare state that offers equal educational opportunities for everyone, however, chronically ill adolescents can add to their resources for coping through schooling. Health related selection thus works differently for various indicators of health and in various kinds of societies. Social class differences in health in the future may be more dependent on personally experienced heath problems than on medically diagnosed diseases.
\end{abstract}

\section{(f Epidemiol Community Health 1995;49:131-138)}

Three models - artefactual, causal, and selectional - have been proposed to explain social inequality in health. According to the selectional model, health determines social class through a process by which healthy people are more likely to move up the social hierarchy, and unhealthy people to move down. ${ }^{1}$ This process might mean that unhealthy people are not capable of acquiring a good education. As a result, their chances of entering the labour market in general, and their chances of attaining higher social positions in particular, are reduced. ${ }^{2}$ Two types of selection have been described. The first, direct selection, regards health status as a determinant of class position. In the second type, indirect selection, a common background factor affects both health status and social position. ${ }^{3}$ One possible factor is the parents' socioeconomic position, but individual characteristics such as height and intelligence may also influence health and social position. ${ }^{4}$

Published studies on the healthy worker effect provide evidence that there is health related selection in adult life. ${ }^{562}$ There is also considerable research which shows that being tall is associated with many kinds of success in life..$^{7-12}$ Height is then supposed to measure health or health potential as a consequence of childhood living conditions. ${ }^{713-15}$ Except for long term illness, ${ }^{16}$ there are only a few studies that use other indicators of health in youth, and the role of education in the selection process has been overlooked. Health selection, however, has been taken as a possible explanation for the phenomenon that class differences in health care are not evident in youth but emerge soon afterwards. ${ }^{17}$

Depending on the type of illness, there are different kinds of problems in intellectual development, social coping, and school achievement, influenced by many factors in the family, school, and society. ${ }^{18}$ Functional impairment or chronic health problems which are likely to interfere with peer communication or to reduce school attendance, as well as psychological problems, have an especially adverse effect on school outcomes. ${ }^{19}$ The process of allocating individuals an occupational social class via the educational system is thus sociological in nature. Health, as well as other individual attributes, take on different meanings depending on their relative importance for success in a particular society.

In almost all societies, people with visible illnesses or handicaps suffer from many kinds of negative attitudes and prejudices. ${ }^{186}$ The stigma, or fear of possibly becoming stigmatised, may cause problems with self esteem and identity. This, in turn, restricts capacities and aspirations and thus reduces educational and occupational achievement. Discrimination may lead to lowered educational expectations and to self fulfilling prophecies. ${ }^{920-24}$

Because of its dependence on societal factors, the generally supposed direction of health re- 
lated selection may be criticised. Even a severe illness does not necessarily mean that someone will not receive any education. Many severely ill children are particularly motivated in terms of intellectual work and circumvent the impairment by compensating creatively for it. ${ }^{1925-27}$ In a welfare state that provides free education right up to university level, it seems more probable that ill people will continue to study rather than take a manual job. This would lead to ill health increasing the chances of belonging to higher social groups, thus concealing class differences in health. ${ }^{16}$ Health related selection is not therefore a uniform phenomenon, but works differently for different diseases and for different groups of people, and is dependent on the type of society.

Education nowadays plays a fundamental role in shaping an individual's life chances and social status. While, previously, skills learned in work were useful capital on the labour market, now with the highly specialised occupational structure, even entering paid labour is difficult without an adequate education. Now there is a polarisation into two strata - the highly educated elite and the less educated, marginalised people, deprived in many fields of life. In Finnish society, an individual's socioeconomic status and social standing are related more obviously to his education than in many other countries. ${ }^{28}$ As a result of rapid social and economic change, and the expansion of the functions of the welfare state, faith in education as a guarantee of good social position has been justified, at least until now. ${ }^{29}$

Along with the rising level of education in the labour force, the fight for places has become harder, and a proportion of each generation is left either outside education or without employment corresponding to their education. It has been estimated that from $2 \%{ }^{30}$ to $10 \%{ }^{31}$ of each Finnish birth cohort is at risk of becoming marginalised from society. In 1986, the unemployment rate in people without vocational education was $11 \%$, while it was $5 \%$ in people who had acquired vocational education. ${ }^{32}$ Several studies show that dropping out of school places a person at risk of a lifetime of personal and career problems, as well as creating problems for society at large. ${ }^{33-35}$

Besides producing a qualified labour force, the other goal set for education is to promote equality and democracy. Schooling is considered an end in itself, a resource that influences other factors in an individual's lifestyle and standard of living. ${ }^{36} \mathrm{It}$ is strongly connected with social coping capabilities and control over one's own life, with possibilities for acquiring knowledge, and with the ability to utilise new information. There has been a great faith in the idea that both the economic and equalizing goals could be reached by creating a system that offers people from all social backgrounds maximum equality of educational opportunity right through to higher education. In Finland, this thinking was reflected in a continuous expansion of public expenditure on education throughout the $1980 \mathrm{~s}$. At the beginning of the 1990 s, $13 \%$ of the group aged 20-24 years were studying in universities. ${ }^{3738}$
The educational system of Finland differs greatly from those in America and Britain. ${ }^{3940}$ Children go through a comprehensive system from the age of 7 years, and education is compulsory up to the age of 16. Dropping out of school before this age is extremely rare. At an average age of 16 , adolescents continue their studies either in upper secondary schools or in vocational education. The decision made at this point is crucial for their future, because upper secondary school is still practically the only route to a university education. Theoretically, all children have an equal chance of attending all levels of education, but equality according to social background has not been attained in reality. Children of highly educated white collar families still end up with the most education. ${ }^{41-45}$

This study aimed to investigate the association of health in adolescence with the chosen educational path, and thus to learn about the contribution of the selectional model in explaining the formation of health differences between social groups. This was done by finding out whether some measures of a young person's health were, independently of social background, associated with the choice of educational path after the completion of compulsory schooling. Educational pathway is one way of measuring social position in young people. The concept of the social group is problematic at this age, because of the shift from the social position of origin to that based on a young person's own achievements. ${ }^{174}$ An association between health in youth and the chosen educational career may be an indication that there is a health related social selection into different types of careers, which, in turn, anticipates the range of possible social positions in adulthood.

\section{Methods}

The study is a part of the adolescent health and lifestyle survey, focussed on Finnish adolescents. Data were collected in 1987 by postal questionnaires sent to a national sample of $12,14,16$, and 18 year old Finns. The first questionnaire was sent in February and was followed by two further questionnaires to nonrespondents. All those born between 14 and 31 July were included in the sample, which was drawn from the National Population Register Centre. In this study, only the 16 year olds are considered, because by that age the division into those who are or are not going to continue their studies has generally taken place. The total sample comprised 2977 adolescents. The final number of respondents included in analyses was 2467 . The response rate was $83 \%$ : $77 \%(n=1183)$ in boys and $89 \%(n=1284)$ in girls. In relation to the geographical region of residence, the response rate was lowest $(79 \%)$ in central west Finland and highest $(88 \%)$ in the north.

The questionnaire was voluntary and the purpose of the study was explained in a covering letter. The study protocol was accepted by the ethical committees of the University of Helsinki and of the Department of Public Health. 
OUTCOME VARIABLES

The outcome variables were chosen to form a hierarchy, reflecting successive steps on the ladder to educational achievement. The first of these was a dichotomous variable called school attendance, which indicated whether the respondent was $(92 \%)$ or was not $(8 \%)$ attending school at the time of inquiry. The second one, the type of school, divided the students into two categories: upper secondary school $(55 \%)$ or vocational and other (mostly vocational school or institute or some other school or institute) $(45 \%)$. The third variable was school achievement, measured by the pupil's own assessment of his or her position in the class, according to the average school marks in the preceding end of term school report. Pupils with an above average report belonged to the first group $(43 \%)$ and those with an average level or below average level school report formed the second group (57\%).

\section{INDEPENDENT VARIABLES}

The independent variables were divided into two main categories as follows.

\section{Socioeconomic background}

Father's or other guardian's education was defined according to the number of years of education as: low (at most, 8 years), middle (from 8 to 11 years), or high (12 or more years).

Father's or other guardian's occupation was classified by the 1970 status classification of the Central Statistical Office of Finland as: upper white collar worker, lower white collar worker, farmers, or blue collar worker.

The urbanisation level of the place of residence was defined by the population density as: capital area (Helsinki and the adjoining towns), large town (population over 100000 ), small town/village (densely populated areas in rural type municipalities) and, sparsely populated rural municipalities (isolated homesteads in rural type municipalities).

The five geographical regions of residence, described the south-north dimension, the most industrialised areas being in the south and south west, these were: south (provinces of Uusimaa and Kymi), south west (provinces of Turku and Pori, Häme), central west (provinces of Keski-Suomi, Vaasa), east (provinces of Kuopio, Pohjois-Karjala, Mikkeli), and north (provinces of Oulu, Lappi).

Family type was dichotomous: either a nuclear family (living with both parents) or nonnuclear family (parents divorced, father, mother or both dead or not living with parents).

Health

All information was self reported. The following variables were used:

Chronic illness, disability, and/or continuous medication prescribed by a doctor: no/yes. Severely handicapped adolescents who could not fill in a self administered questionnaire were not included in the study.
Height: the values were divided into four classes, using the distribution quartiles as cut off points; the information was reported to an accuracy of $1 \mathrm{~cm}$ and the quartiles were calculated separately for boys and girls.

The number of influenza episodes during the preceding six months: at least two, one, or none.

The number of diagnosed new dental caries during the preceding two years in people who had visited a dentist: more than once, once, or not at all. The $3 \%$ of respondents who had not visited a dentist were classified as "missing data".

The number of medical consultations during the preceding two years grouped as: three or more, two, one, or none.

Perceived health at the time of inquiry: bad (combines classes very bad and bad), moderate, and good (combines classes quite good and good).

Use of over the counter medicines during the preceding month, for headache or other pains, cold or fever, cough, insomnia, stress or anxiety, abdominal pains or constipation or other ailments: yes/no.

Tiredness in the daytime at the time of inquiry: more than school friends or no more than school friends.

Feeling active in the morning at the time of inquiry: seldom or never, occasionally, or every morning or quite often.

Number of symptoms occurring at least weekly; a sum index constructed of nine symptoms felt weekly or more often, during the preceding six months (abdominal pains, anxiety, irritability or fits of anger, difficulties in sleeping, headache, tremor of hands, fatigue or weakness, fits of dizziness, pains in head or neck): at least three symptoms, two, one, or none.

\section{STATISTICS}

For each outcome variable, stepwise logistic regression analyses were performed in two phases. Firstly, those socioeconomic background variables that showed independent associations with the outcome variables were selected. Then, to get the final multivariate model of health variables which were independently associated with the outcome variable, a stepwise procedure was used, with adjustment for the background variables selected above. For school achievement, the analyses were made separately for upper secondary schools and for vocational or other schools. The odds ratios (OR) with $95 \%$ confidence intervals (CI) were calculated for the variables showing significant explanatory power in the final model. Decisions regarding statistical significance were made on the $5 \%$ risk level. The analyses were carried out using the LR program in the statistical software $B M D P{ }^{47}$ The logistic regression functions were computed using only the cases which had values for every variable. The number of cases with missing data varied between 5 and $14 \%$ of the respondents in different models. 
Table 1 The distribution of further education in relation to gender in a sample of Finnish 16 year olds

\begin{tabular}{lrrr}
\hline Educational career & $\begin{array}{l}\text { Boys } \\
(\%)\end{array}$ & $\begin{array}{l}\text { Girls } \\
(\%)\end{array}$ & $\begin{array}{l}\text { Total } \\
(\%)\end{array}$ \\
\hline Upper secondary school & 41 & 60 & 51 \\
Vocational or other school & 51 & 32 & 41 \\
Not attending school & 8 & 8 & 8 \\
Total & 100 & 100 & 100 \\
No & 1257 & 1021 & 189 \\
\hline
\end{tabular}

Table 2 Factors associated with school attendance: $p$ values of the model and odds ratios with $95 \%$ confidence intervals

\begin{tabular}{|c|c|c|c|}
\hline Independent variable & $p$ value & $O R$ & $(95 \% C I)$ \\
\hline \multicolumn{4}{|l|}{ Socioeconomic background } \\
\hline Father's occupation: & 0.0015 & & \\
\hline Blue collar worker & & 1.00 & \\
\hline Farmer & & 0.65 & $(0.39,1.08)$ \\
\hline Lower white collar worker & & $1 \cdot 18$ & $(0 \cdot 79,1 \cdot 76)$ \\
\hline Upper white collar worker & & $3 \cdot 13$ & $(1.54,6.36)$ \\
\hline Family type: & 0.030 & & \\
\hline Non-nuclear family & & $1 \cdot 00$ & \\
\hline Nuclear family & & 1.52 & $(1 \cdot 04,2 \cdot 22)$ \\
\hline \multicolumn{4}{|l|}{ Health* } \\
\hline No of new caries: & 0.0002 & & \\
\hline$>1$ & & 1.00 & \\
\hline 1 & & $1 \cdot 35$ & $(0.90,2 \cdot 04)$ \\
\hline 0 & & $2 \cdot 45$ & $(1 \cdot 60,3 \cdot 74)$ \\
\hline No of symptoms occurring at least weekly: & 0.0068 & & \\
\hline$\geqslant 3$ & & 1.00 & \\
\hline 2 & & 1.92 & $(1 \cdot 12,3 \cdot 31)$ \\
\hline 1 & & $2 \cdot 02$ & $(1 \cdot 21,3 \cdot 37)$ \\
\hline 0 & & 1.85 & $(1 \cdot 22,2 \cdot 81)$ \\
\hline Chronic illness, or disability, or medication & $0 \cdot 017$ & & \\
\hline Yes & & 1.00 & \\
\hline No & & 0.46 & $(0.24,0.87)$ \\
\hline
\end{tabular}

* For health variables, adjustment for the socioeconomic background variables presented above was made.

Table 3 Factors associated with the type of school. $p$ values of the model, and odds ratios with $95 \%$ confidence intervals

\begin{tabular}{|c|c|c|c|}
\hline Independent variable & $p$ value & $O R$ & $(95 \% C I)$ \\
\hline \multicolumn{4}{|l|}{ Socioeconomic backgmound } \\
\hline Father's occupation: & $<0.0001$ & & \\
\hline Blue collar worker & & 1.00 & \\
\hline Farmer & & $1 \cdot 43$ & $(1.02,2.01)$ \\
\hline Lower white collar worker & & 1.90 & $(1 \cdot 48,2 \cdot 43)$ \\
\hline Higher white collar worker & & $3 \cdot 37$ & $(2 \cdot 21,5 \cdot 15$ \\
\hline Gender: & $<0.0001$ & & \\
\hline Male & & 1.00 & \\
\hline Female & & 2.90 & $(2 \cdot 35,3 \cdot 58)$ \\
\hline Father's education: & $<0.0001$ & & \\
\hline Low & & $1 \cdot 00$ & \\
\hline Middle & & 1.73 & $(1 \cdot 24,2 \cdot 41)$ \\
\hline High & & $4 \cdot 08$ & $(2 \cdot 46,6 \cdot 75)$ \\
\hline Family type: & $<0.0001$ & & \\
\hline Non-nuclear family & & 1.00 & \\
\hline Nuclear family & & $1 \cdot 70$ & $(1 \cdot 33,2 \cdot 17)$ \\
\hline \multicolumn{4}{|l|}{ Health* } \\
\hline Perceived health: & 0.0001 & & \\
\hline Bad & & $1 \cdot 00$ & \\
\hline Moderate & & $1 \cdot 72$ & $(1 \cdot 31,2 \cdot 24)$ \\
\hline Good & & 1.86 & $(1 \cdot 38,2.51)$ \\
\hline No of medical consultations: & 0.0062 & & \\
\hline$\geqslant 3$ & & $1 \cdot 00$ & \\
\hline 2 & & 1.02 & $(0 \cdot 76,1 \cdot 37)$ \\
\hline $\begin{array}{l}1 \\
0\end{array}$ & & $\begin{array}{l}1.60 \\
1.19\end{array}$ & $\begin{array}{l}(1.21,2.13) \\
(0.91,1.56)\end{array}$ \\
\hline No of new caries lesions: & 0.030 & & \\
\hline$>1$ & & $1 \cdot 00$ & \\
\hline 1 & & 1.09 & $(0.83,1.43)$ \\
\hline 0 & & $1 \cdot 37$ & $(1.07,1 \cdot 76)$ \\
\hline Height: & 0.027 & & \\
\hline Shortest quartile & & $1 \cdot 00$ & \\
\hline Second quartile & & $1 \cdot 34$ & $(1.01,1.77)$ \\
\hline Third quartile & & 1.43 & $(1 \cdot 09,1 \cdot 87)$ \\
\hline Tallest quartile & & 1.46 & $(1.09,1.97)$ \\
\hline
\end{tabular}

* For health variables, adjustment for the socioeconomic background variables presented above was made.

\section{Results}

Most of the adolescents continued their education after the compulsory phase. Attending upper secondary schools was more typical of girls than of boys, who more often chose vocational education (table 1 ).

\section{SCHOOL ATTENDANCE}

The background variable most strongly, independently related to school attendance was father's occupation (table 2). The likelihood of continuing studies was highest in the upper white collar families. In addition, family type was independently associated with attendance, with adolescents from nuclear families more likely to continue their education than adolescents from other kinds of families.

When the social background was taken into account, three health variables had a significant independent association with school attendance in the final, best fitting model (table 2). Adolescents who continued their education had fewer new caries lesions during the preceding six months. The association with chronic illness was the opposite - adolescents with chronic illness were more likely to continue their studies than the healthy ones.

TYPE OF SCHOOL

The type of school was strongly related to background variables (table 3 ). Again, the most important factor was the father's occupation. Choosing an upper secondary school was least typical in blue collar families, and most typical in upper white collar families. Girls were more interested in upper secondary education than boys. Independently of occupation, father's education had an influence on the choice of the type of school: the higher the father's education, the more probable was attendance at upper secondary school. This type of school was selected more frequently in nuclear families than in other families.

Four health variables appeared in the final model (table 3). Compared to young people in vocational and other schools, those in upper secondary schools had better perceived health, a smaller number of medical consultations, more often belonged to higher height quartiles, and had a smaller number of new dental caries.

\section{SCHOOL ACHIEVEMENT IN UPPER SECONDARY} SCHOOLS

In upper secondary schools, above average achievement was most often found in adolescents from families with highly educated fathers (table 4). In upper secondary schools, girls did better than boys. In the final analysis, one health variable significantly improved the fit of the model (table 4). Doing well was characteristic of young people with moderate or good perceived health.

\section{SCHOOL ACHIEVEMENT IN VOCATIONAL AND} OTHER SCHOOLS

In stepwise analysis, the geographical region of 
Table 4 Factors associated with good school achievement in adolescents attending upper secondary schools. $p$ values of the model and odds ratios with $95 \%$ confidence intervals

\begin{tabular}{|c|c|c|c|}
\hline Independent variable & p value & OR & $(95 \% C I)$ \\
\hline $\begin{array}{l}\text { Socioeconomic background } \\
\text { Father's education: }\end{array}$ & \multirow[t]{4}{*}{0.011} & & \\
\hline Low & & 1.00 & \\
\hline Middle & & $1 \cdot 29$ & $(0.93,1.79)$ \\
\hline High & & 1.58 & $(1 \cdot 16,2 \cdot 15)$ \\
\hline Gender: & \multirow[t]{3}{*}{0.025} & & \\
\hline Male & & 1.00 & \\
\hline Female & & $1 \cdot 33$ & $(1 \cdot 04,1 \cdot 72)$ \\
\hline \multicolumn{4}{|l|}{ Health* } \\
\hline Perceived health: & 0.0071 & & \\
\hline Bad & & $1 \cdot 00$ & \\
\hline Moderate & & 1.42 & $(1 \cdot 01,2 \cdot 01)$ \\
\hline Good & & $1 \cdot 81$ & $(1.25,2.63)$ \\
\hline
\end{tabular}

* For health variables, adjustment for the socioeconomic background variables presented above was made.

Table 5 Factors associated with good school achievement in adolescents attending vocational and other schools. $p$ values of the model, and the odds ratios with their $95 \%$ confidence intervals

\begin{tabular}{|c|c|c|c|}
\hline Independnt variable & $p$ value & OR & $(95 \% C I)$ \\
\hline $\begin{array}{l}\text { Socioeconomic background } \\
\text { Geographical region of residence: } \\
\text { South } \\
\text { South west } \\
\text { Central west } \\
\text { East } \\
\text { North }\end{array}$ & 0.033 & $\begin{array}{l}1 \cdot 00 \\
1 \cdot 14 \\
1 \cdot 12 \\
0 \cdot 72 \\
1 \cdot 40\end{array}$ & $\begin{array}{l}(0 \cdot 65,1 \cdot 98) \\
(0.65,1.94) \\
(0.44,1 \cdot 18) \\
(0 \cdot 86,2 \cdot 28)\end{array}$ \\
\hline $\begin{array}{l}\text { Health* } \\
\text { Chronic illness, or disability, or medication } \\
\text { prescribed by doctor: }\end{array}$ & 0.0014 & & \\
\hline $\begin{array}{l}\text { Yes } \\
\text { No } \\
\text { No of symptoms occurring at least weekly: }\end{array}$ & 0.035 & $\begin{array}{l}1.00 \\
0.50\end{array}$ & $(0.32,0.76)$ \\
\hline $\begin{array}{l}\geqslant 3 \\
2 \\
1 \\
0\end{array}$ & & $\begin{array}{l}1 \cdot 00 \\
1 \cdot 25 \\
1 \cdot 24 \\
1 \cdot 85\end{array}$ & $\begin{array}{l}(0 \cdot 75,2 \cdot 10) \\
(0 \cdot 74,2 \cdot 06) \\
(1 \cdot 18,2 \cdot 89)\end{array}$ \\
\hline $\begin{array}{l}\text { Use of over the counter medicines: } \\
\text { Yes } \\
\text { No }\end{array}$ & 0.039 & $\begin{array}{l}1.00 \\
0.72\end{array}$ & $(0.52,0.98)$ \\
\hline $\begin{array}{l}\text { Tiredness in the daytime: } \\
\text { More than school friends } \\
\text { No more than school friends }\end{array}$ & 0.043 & $\begin{array}{l}1.00 \\
1.57\end{array}$ & $(1 \cdot 01,2 \cdot 42)$ \\
\hline
\end{tabular}

* For health variables, adjustment for the socioeconomic background variables presented above was made.

residence was the only background variable that was significantly associated with good school achievement (table 5).

The probability of having had a good school report was higher in adolescents with a chronic illness than in the healthy ones (table 5). Clearly, pupils who had not had weekly symptoms did better than those who had suffered from symptoms. Tiredness in the daytime was typical of those not doing well at school. The use of over the counter medicines was associated with doing well at school.

\section{Discussion}

The distribution of educational careers, in both genders, was similar in this study to the respective distribution in official Finnish statistics of the mid and late $1980 \mathrm{ss}^{4849}$ Thus, the fact that boys were less active than girls in returning the questionnaire, had not caused distortion in this respect.

\section{SOCIOECONOMIC BACKGROUND}

The decision to continue education at age 16 and the choice of school type, were dependent on social background. This agrees with pre- vious findings, showing the unchanged power of social background in the formation of a young person's educational career. ${ }^{41-454650}$ Socioeconomic background is related to the material resources available to children and the family's educational values. ${ }^{193351}$ Parents in different social groups are, to varying degrees, involved in their children's school work and in their plans for the future. ${ }^{334151-53}$ School practices may also favour children whose families have a positive attitude to education. ${ }^{4254-57}$ Father's occupation and education were independently associated with the type of school, which may mean that highly educated parents even in lower status occupations put great value on studies offering the possibility of going on to higher education.

Children from social backgrounds that do not give much weight to education, probably do not trust education as a source of social advancement. For them, school may become a place of failure, which leads to withdrawal. ${ }^{338-61}$ Adolescents who are studying with minor resources, may more easily than others experience low achievement and setbacks as obstacles to continuing their education. ${ }^{62}$ For some groups of people it is important to stabilise the basic structures of life, like work and children at a young age. ${ }^{6364}$ This may partly explain why children in blue collar and farming families are less eager to go on with their studies. Thus, remaining outside education may be either an autonomic decision or the result of a selection process. ${ }^{65}$

The power of father's education extended to achievement in upper secondary school. Thus, even among those who had chosen the route leading to the highest level of education, there was the division into two groups, the successful children of highly educated parents and the less academic or less motivated children of other families. Adolescents attending vocational education were already a selected group according to family background, and among them father's education did not play any role with regard to school achievement.

The type of family seemed to have a role in the educational career. This agrees with previous findings, that parental separation or living in one parent families is associated with school problems. ${ }^{6667}$ Living with one parent may influence school achievement negatively either via the economic deprivation caused by the lack of a second parent's earnings ${ }^{68}$ or via the student's misbehaviour, caused by the frustrating and distracting life situation. Whatever the mechanism, young people from single parent homes, irrespective of whether they live with their mothers or fathers, are less likely to connect with school and to meet the school's demands. ${ }^{6669}$ Good relations between children and parents increase the chances of doing well in school. ${ }^{5270-74}$

European studies have shown that equality in relation to gender has increased more than equality in relation to social background during recent decades. ${ }^{50}$ In this study, continuing with education was equally popular among both sexes, but girls favoured going to upper secondary schools and boys to vocational edu- 
cation, independently of father's occupational status. Gender was also associated with school achievement, independently of father's education, but only in upper secondary schools. It has been noticed that in school, boys are more often labelled as troublemakers, and that pupils in observation classes are generally boys. ${ }^{75}$ Girls, and especially those from educated families, adapt to school life because teachers are mostly women, who represent a middle class way of life. ${ }^{76}$

\section{HEALTH}

School career was connected with health, independently of social background. Good health status, as measured by various indicators, was typical of adolescents who had decided to go on with education, who went to upper secondary schools, or who did well in either of the two types of schools. The interpretation of the associations is problematic, because the indicators of health used in this study may reflect the health status of the present moment or they may have their origin in an earlier phase of life.

It may be that in societies where education is generally highly valued, those who successfully aim at high levels enjoy living in harmony with the societal norms. They thus feel satisfied, and this is seen as good perceived health and few symptoms. For those who drop out of education or experience difficulties in finding their place in a society where taking advantage of educational opportunities is desirable, the conflict with norms may cause stress and discontent, which is seen as bad perceived health and many symptoms. ${ }^{77-80}$ However, the opposite is also possible, so that for adolescents who have generally felt well, success in education is easier to attain. All in all, school seems to impose demands on young people, and thus brings to the surface the differences in personal health related resources. The process is probably chain-like in that health both affects the school career and is influenced by it. ${ }^{81}$

Without a properly longitudinal study design, one must be very cautious about the causal impact of health on school career. In this study, only two of the independent variables, chronic illness and height, could be regarded as describing the more permanent health status. Of these two variables, height was associated with success in a similar way to many previous studies. ${ }^{710-12}$ Height had an importance independently of home background, which is an indication that it involves something more than the impact of childhood living conditions. ${ }^{13148283}$ Indirect height related selection may work here, for example, via discrimination according to attractiveness. Height and attractiveness have been found to correlate with each other, independently of social class. Taller people are perceived as being more attractive and are attributed with other desirable characteristics, such as intelligence or competence, which brings them many kinds of social advantage. ${ }^{9}$ In school, this might mean that taller adolescents have more self esteem and a positive impression of their chances of advancing in their educational career.
Compared with the other health variables, chronic illness functioned in the opposite way. Chronically ill adolescents were more likely to continue their studies than the healthy ones, which is understandable in a welfare state, like Finland, which provides free education up to university level. This is not the case in many other societies where, due to strong prejudices, handicapped adolescents are offered few educational opportunities. ${ }^{24}$ Education gives ill people a possibility to compensate for their illness ${ }^{18}$ and to create abilities for controlling their lives. ${ }^{25}$ To manage in life, an ill person must greatly depend on qualifications gained through education, and this probably increases motivation at school. Also, when it is not possible to orientate oneself towards physical activities as much as one's peers, another possibility is to turn to studying. ${ }^{2627}$ It must, however, be remembered that the very severely handicapped adolescents, who could not fill in a self administered questionnaire, were excluded from the study.

The role of chronic illness in the educational career thus contradicts the generally assumed hypothesis with regard to the direction of health related selection. It is not a uniform phenomenon, but works differently for various indicators of health and in various kinds of societies and age groups. Some states of health may directly affect the career, but more probably there are social factors involved, giving different meanings to various states of health. ${ }^{2428}$ It is also possible that people with mild illnesses are left in the middle, without the support and understanding which the severely sick receive ${ }^{85}$ and thus will have more difficulties. Theoretical developments, putting health related mobility into its rightful place, among other processes of social life, are needed.

\section{Conclusion}

The three outcome variables were treated as successive steps on the way to educational success. There are associations between the variables, which can only be identified by longitudinal designs. School achievement is known to influence the selection of educational careers, by modifying the motivation and goals which are set for education, as well as opinions regarding a person's own talents and capacities. ${ }^{86-89}$ Young people who choose the upper secondary school route generally have better school reports, than those who choose vocational education after compulsory schooling. ${ }^{404190}$ Thus, by the time a person has reached the age of 16 , school achievement has already played a central role, when educational decisions have been made. In a cumulative way, it summarises a person's positive and negative school experiences right from the first school day, and thus should also be taken into consideration as a mediating factor in a process through which the person's educational career is shaped.

Regardless of socioeconomic background, the health resources of a young person are related to the formation of his or her educational career: good perceived health is typical of those whose careers may lead to high social 
positions. In a welfare state, the inconveniences caused by chronic illness or handicap are likely to be compensated for by education. Health related social selection thus seems to work differently for various indicators of health. Further research is needed to clarify which intervening social factors play a role in creating opportunities for social promotion in various kinds of societies. Among these might be the quality of educational opportunities and the social welfare services for people with health problems, prejudices against different types of illnesses and other personal characteristics that influence success at school, and life ideals in various cultural subgroups with corresponding lifestyles. In proving the validity of theoretical developments which relate health selection with other processes of social life in the reproduction of the social class structure, longitudinal study designs are essential.

1 Blane D. An assessment of the Black report's explanation of health inequalities. Sociology of Health and Illness 1985; 7:423-445.

2 Karisto A. Sosiaalluokka ja sairastavuus. Tutkimus muutoksista vuosina 1964-1987. Sosiaalilääket Aikak 1990;27: 43-54.

3 Wilkinson R. Socio-economic differences in mortality: interpreting the data on their size and trends. In: Wilkinson $\mathrm{RG}$, ed. Class and health. Research and longitudinal data. Tavistock. London 1986

4 Lahelma E. Sukupuolten eriytyminen peruskoulun opetussuunnitelmassa. Kasvatustieteiden laitoksen tutkimus 132. Helsinki: Helsingin yliopisto, 1992

5 Östlin P. Negative health selection into physically light occupations. 7 Epidemiol Community Health 1988;42:152 156.

6 Bartley M. Unemployment and health: selection or causation - a false antithesis? Sociology of Health and Illness 1988;10. 41-67.

7 Macintyre S. Social correlates of human height. Sci Prog 1988;72:493-510.

8 Illsley R. Social class selection and class differences in relation to stillbirths and infant deaths. BMF 1955;ii: 1520-1524.

9 West P. Rethinking the health selection explanation for health inequalities. Sociology of Health and Ilness 1991;32: 373-84

10 Power C, Fogelman K, Fox AJ. Health and social mobility during the early years of life. Quarterly fournal of Social Affairs 1986;2:397-413.

11 Nyström Peck AM. Childhood environment, intergenerational mobility, and adult health - evidence from $71-4$.

12 Marmot MG. Social inequalities in mortality: the social environment. In: Wilkinson RG, ed. Class and health.
Research and longitudinal data. Tavistock. London 1986.

13 Rona RJ, Chinn S. Father's unemployment and height of primary school children in Britain. Ann Hum Biol 1991; 18:441-8.

14 Kuh D, Wadsworth $M$. Parental height: Childhood environment and subsequent adult height in a national birth cohort. Int $\mathcal{F}$ Epidemiol 1989;18:663-8.

15 Macintyre S. A review of social patterning and significance of measures of height, weight, blood pressure and respiratory function. Soc Sci Med 1988;27:327-37.

16 Lundberg O. Class position and health: social causation or social selection? Stockholm: Swedish Institute for Social Research, University of Stockholm. Meddelande 8/1988.

17 West P. Inequalities? Social class differentials in health in British youth. Soc Sci Med 1988;27:291-6.

18 Urponen H. Early adulthood life of chronically impaired and disabled children. $A$ sociological follow-up study of social coping of chronically ill and disabled children in early adulthood. Tampere: Annales Universitatis Turkuensis, 1989. Ser C OSA-TOM. 78. (English summary).

19 Wolfe BL. The influence of health on school outcomes. A multivariate approach. Med Care 1985;23:1127-38.

20 Goffman E. Stigma. Notes on the management of spoiled identity. New York: Prentice-Hall, 1963.

21 Scambler G. Epilepsy. London: Tavistock-Routledge, 1989. Scambler G, Hopkins A. Being epileptic: coming to terms

23 Schneider LW, Conrad P. Having epilepsy: the experience and control of illness. Philadelphia: Temple University Press, 1983.

24 Jenkins R. Disability and social stratification. British fournal of Sociology 1991;42:557-580.

25 Gerber PJ, Reiff HB. Speaking for themselves: ethnographic interviews with adults with learning disabilities. Ann Arbor: The University of Michigan Press, 1992.

26 Hanford HA, Mayes SD, Bixler ED, Mattison RE. Per- sonality traits of haemophilic boys. $\mathcal{F}$ Dev Behav Pediatr 1986;7:224-9.

27 Kvist B, Kvist M, Rajantie J. School absences, school achievements and personality traits of the haemophilic child. Scand 7 Soc Med 1990;18:125-32.

28 Keltikangas-Järvinen L. Self-esteem as a predictor of future school achievement. European fournal of Psychology of Education 1992;7:123-30.

29 Sulkunen P. Häviävät erot - uudet keskiluokat länsieurooppalaisessa yhteiskunnassa. Sosiologia 1992;29: 203-18.

30 Mustola K. Ilman työtä elävät nuoret. $A V O$ 1991;3-4:40-45. 31 Torniainen H. Nuorten syrjäytymiskartoitus Oulussa. (Käsikirjoitus). Oulu: Merikosken kuntoutus- ja tutkimuskeskus, 1992

32 Koulutus ja ammatit 1986. Tilastokeskuksen työvoimatutkimus 1988:2; Helsinki 1988.

33 Persaud D, Madak PR. Graduates and dropouts: comparing perceptions of self, family, and school supports. The Alberta perceptions of self, family, and school supports. The

34 Kivinen $O$, Toivola $H$, Ahola $S$. Nuorten valikoituminen ammattikouluttamattomiksi työnhakijoiksi. Kolmen työvoimatoimiston nuorten yksiköiden alle 20-vuotiaa asiakkaat ammatti- ja koulutusvalintojensa edessä. Työvoimapoliittisia tutkimuksia 81. Helsinki: Työvoimaministeriön suunnitteluosasto, 1988

35 Nurmi JE, Salmela-Aro K, Anttonen M, Kinnunen $H$ Epäonnistumisen psykologiaa. Syrjäytymisvaarassa olevien nuorten kiinnostukset ja ajattelutavat. Psykologia 1992;27:485-92.

36 Allardt E. Hyvinvoinnin ulottuvuuksia. Juva: WSOY, 1976. Kivinen O, Rinne R. Investment in higher education: the Finnish experience. Higher Education Policy 1992;5:50-54.

38 Education and Research 1991:15. Korkeakouluopiskelijat syyslukukaudella 1991. Helsinki: Central Statistical Office in Finland (VAPK), 1991.

39 Husen T, Postlethwaite TN, eds. The international encyclopaedia of education. Exeter: Pergamon Press, 1985.

40 Kivirauma J, Silvennoinen $\mathrm{H}$. Tension between the uppe secondary school and vocational education in Finland. Nondisk Pedagogik 1992;3:157-65.

41 Kuusinen J. Lukioon siirtyneiden lahjakkuus ja sosiaalinen tausta. Sosiologia 1985;22:191-6.

42 Silvennoinen H, Laiho I. Akateeminen koulutushierarkia sukupuoli ja sosiaalinen tausta. Sosiologia 1992;29:294 309.

43 Hermunen $\mathrm{H}$. Oppilaiden sosiaalinen tausta. Helsinki: Tilastokeskus, 1984 Tutkimuksia 111/1984.

44 Husen T. Higher education social stratification: an international comparative study. Fundamental of educational planning 34. Paris: Unesco. International Institute for Educational Planning, 1987.

45 Isoaho H, Kivinen O, Rinne R. Nuorten koulutus ja kotitausta. Helsinki: Tilastokeskus, 1990. Tutkimuksia 171

46 Goldthorpe J. Social mobility and class structure in modern Britain. Clarendon Press. Oxford 1980.

47 Dixon WJ, ed. BMDP statistical software manual. Berkeley: University of California Press, 1990.

48 Education and Research. Oppilaiden ikä ja osuus väestöstä 1990. Helsinki: Central Statistical Office in Finland, 1992 49 Education and Research 1987:5. Oppilaiden ikä vuonna 1985. Helsinki: Central Statistical Office in Finland, 1987. 50 Cobalti A. Schooling inequalities in Italy: trends over time. European Sociological Review 1990;6:199-214.

51 Kuh D, Wadsworth M. Childhood influences on adult male earnings in a longitudinal study. British fournal of Sociology $1991 ; 72: 437-55$

52 Steinberg L, Lamborn SD, Dornbusch SM, Darling N. Impact of parenting practices on adolescent achievement: authoritative parenting, school involvement, and encouragement to succeed. Child Development 1992;63: 1266-81.

53 Useem EL. Middle schools an math groups: parents' involvement in children's placement. Sociology of Education 1992;65:263-79.

54 Broady D. Piilo-opetussuunnitelma. Mihin koulussa opitaan. Tampere: Vastapaino, 1986

55 Kivinen O, Rinne R, Kivirauma J. Koulun käytännöt: koulutussosiologinen tarkastelu. Turun: Turun yliopisto, 1985. Turun yliopiston kasvatustieteiden tiedekunnan julkaisuja A: 105 .

56 Stenstrom ML. Students' selection in vocational commercial education in Finland. Scandinavian fournal of Educational Research 1992;36:121-31.

57 Bourdieu P, Passeron JC. Reproduction in education, society and culture. London: Sage, 1977.

58 Finn JD. Withdrawing from school. Review of Educational Research 1989;59:117-42.

59 Kysel F, West A, Scott G. Leaving school: attitudes, aspirations and destinations of fifth-year leavers in Tower Hamlets. Educational Research 1992;34:87-105.

60 Willis P. Learning to labor. New York: Columbia University Press, 1977.

61 Howe KR. Liberal democracy, equal educational opportunity, and the challenge of multiculturalism. American Educational Research fournal 1992;29:455-470.

$62 \mathrm{McClelland} \mathrm{KE}$. The social management of ambition. The Sociological Quarterly 1990;31:225-151.

63 Aittola T. Havaintoja yliopiston piilo-opetussuunnitelmasta. Kasvatus 1989;20:218-23.

64 Sinisalo P. Työvoimaura ja yksilön kehitys. Helsinki: Työvoimaministeriön suunnitteluosasto, 1986. Työvoimapoliittisia tutkimuksia 63. 
In: Aukia P, ed. Nuorisoaste valinkauhassa. Helsinki: Otava, 1972

66 Mulkey LM, Crain RL, Harrington AJC. One-parent households and achievement: economic and behavioural explanations of a small effect. Sociology of Education 1992, 65:48-65.

67 Keith V, Finlay B. The impact of parental divorce on children's educational attainment, marital timing, and likelihood of divorce. Fournal of Marriage and the Family 1988;50:797-809.

68 Milne A, Myers D, Rosenthal A, Ginsburg A. Single parents, working mothers, and the educational achievement of
school children. Sociology of Education 1986;59:125-39.

69 McLanahan S. Family structure and the reproduction of poverty. American fournal of Sociology 1985;90:873-90

70 Dornbusch SM, Ritter PL, Leiderman PH, Roberts DF Fraleigh MJ. The relation of parenting style to adolescen school performance. Child Development 1987;58:1244-57.

71 Estrada P, Arsenio WF, Holloway S. Affective quality of the mother-child relationship: longitudinal consequences for children's school-related cognitive functioning. Developmental Psychology 1987;23:210-15.

72 Kurdek LA, Sinclair RJ. Relation of eight graders' family structure, gender and family environment with academic structure, gender and family environment with academic
performance and school behavior. fournal of Educational performance and school

73 Stevenson DL, Baker DP. The family-school relation and the child's school performance. Child Development 1987; 58:1348-57.

74 Weisner TS, Garnier H. Nonconventional family life-style and school achievement: a 12-year longitudinal study. American Educational Research fournal 1992;29:605-32.

75 Kivirauma J. Erityisopetus ja suomalainen oppivelvollisuuskoulu vuosina 1921-1985. Turku: Turun yliopisto, 1989. Annale Universitatis Turkuensis C74.

76 Naumanen P. Tiedon, taidon ja vallan haussa? Miesten ja naisten kouluttautuminen Suomessa. (Käsikirjoitus). Kou- lutussosiologian tutkimuskeskus. Turku: Turun yliopisto, 1993.

77 Aro S. Stress, morbidity and health-related behaviour. Scand F Soc Med 1981;Suppl 25.

78 Honkasalo ML Oireiden ongelma Helsinki: Kansanterveystieteen julkaisuja M 101/1988, 1988.

79 Ahola A. Psyykkisen oireilun sukupuolieroista. Sosiologia 1992;29:23-34.

80 Lazarus RS. The concept of stress and disease. In: Levi L, ed. The psychological environment and psychosomatic diseases. ed. The psychological environment and psych

81 Lahelma E. Ovatko terveydentilan sosioekonomiset erot poistuneet? Sociaalilääket Aikak 1990;27:1-5.

82 Wadsworth $M$. Inequalities in child health. Arch Dis Child 1988; 63:353-5.

83 Rona RJ, Swan AV, Altman DG. Social factors and height of primary schoolchildren in England and Scotland. $\mathcal{F}$ Epidemiol Community Health 1978;32:147-54.

84 Vågerö D. Inequality in health - some theoretical and empirical problems. Soc Sci Med 1991;32:367-71.

85 Pless IB, Pinkerton P. Chronic childhood disorder: promoting patterns of adjustment. Chicago: Yearbook Medical Publishers, 1975

86 Nummenmaa AR, Tarkiainen A. Nuoret koulutuksen ulkopuolella. Nuorisotutkimus 1993;11:28-40.

87 Hautamäki A. Lukioonlähtö ja sosiaaliluokka. Helsinki: Helsingin yliopiston opettajainkoulutuslaitos, 1984. Tutkimuksia no 24.

88 Kivinen R, Kivirauma J. Erikseen ja integroituna: erityisopetus ja -oppilaat suomalaisessa koulujärjestelmässä 1910-1985. Sosiologia 1986;23:295-311.

89 Stenstrom ML. Yhteisvalinnassa koulutuksen ulkopuolelle jääneiden koulutus- ja tyohistoria. Jyväskylä: Jyväskylän yliopisto, 1983. Kasvatustieteiden tutkimuslaitoksen julkaisuja 341.

90 Stenström ML, Määttä $\mathrm{P}$, Jalkanen $\mathrm{H}$, Koulutuksen taitekohdat ja valikoituminen. Kasvatus 1987;18:270-7. 